NBER WORKING PAPER SERIES

\title{
THE POLITICAL ECONOMY OF "TRUTH-IN- ADVERTISING" REGULATION DURING THE PROGRESSIVE ERA
}

\author{
Zeynep Hansen \\ Marc Law \\ Working Paper 11927 \\ http://www.nber.org/papers/w11927
NATIONAL BUREAU OF ECONOMIC RESEARCH 1050 Massachusetts Avenue
Cambridge, MA 02138
January 2006

The views expressed herein are those of the author(s) and do not necessarily reflect the views of the National Bureau of Economic Research.

(C2006 by Zeynep Hansen and Marc Law. All rights reserved. Short sections of text, not to exceed two paragraphs, may be quoted without explicit permission provided that full credit, including $\odot$ notice, is given to the source. 
The Political Economy of "Truth-in-Advertising" Regulation During the Progressive Era Zeynep Hansen and Marc Law

NBER Working Paper No. 11927

January 2006, Revised July 2006

JEL No. M37, K20, N41, N42

\section{$\underline{\text { ABSTRACT }}$}

This paper explores the origins and impact of "truth-in-advertising" regulation during the Progressive era. Was advertising regulation adopted in response to rent-seeking on the part of firms who sought to limit the availability of advertising as a competitive device? Or was advertising regulation desired because it furnished a mechanism through which firms could improve the credibility of advertising? We find the available qualitative and quantitative evidence to be more consistent with the latter hypothesis.

Zeynep Hansen

Olin School of Business

Washington University

Campus Box 1133

St. Louis, MO 63130

and NBER

hansen@olin.wustl.edu

Marc T. Law

Department of Economics

University of Vermont

Old Mill Building

94 University Place

Burlington, VT 05405-0114

marc.law@uvm.edu 


\section{INTRODUCTION}

State regulation of advertising emerged in the early twentieth century. Under the rubric of the "truth-in-advertising movement," a coalition of reformers representing manufacturing, retailing and publishing interests lobbied state governments to enact legislation that made false advertising a misdemeanor. These state laws represented the first broad effort to regulate commercial speech and formed the foundation of subsequent advertising regulation in America. In this paper we explore why these regulations emerged, why these particular interests sought regulation, and what effects these regulations may have had.

It is commonly argued that regulation is the product of rent-seeking by producer interests who seek entry-barriers that increase their profits at the expense of overall welfare (Stigler 1971; Peltzman 1976). Indeed, since Kolko (1963) scholars have argued that Progressive Era regulations like railroad regulation, meat inspection, antitrust, and "blue sky laws" were enacted to tilt the competitive playing field in ways that benefited certain producer groups, harmed consumers, and lowered welfare (Gilligan, Weingast and Marshall 1989; Libecap 1992; Mahoney 2003). In the context of truth-in-advertising regulation, two such hypotheses seem plausible. The first argues that regulation served the interests of a broad coalition of producers and retailers who sought to collectively limit the use of advertising as a competitive device. A second explanation posits that regulation was desired by a subset of smaller, local producers, who wanted to competitively disadvantage the growth of larger, national brands through the regulation of advertising copy. In either case, regulation was designed to benefit producer interests (or a subset of producer interests), harm consumers, and lower overall efficiency. 
An alternative explanation for the emergence of truth-in-advertising regulation posits that the pressure for state-level advertising regulation reflected a real, albeit subtle, concern about the potentially negative consequences of misleading advertising. ${ }^{1}$ The "rotten-apple" hypothesis, which has been advanced by the historical literature on the advertising industry, argues that advertising regulation was adopted because it furnished a mechanism through which firms could collectively improve the credibility of advertising (Kenner 1936; Pease 1958; Pope 1983). During this period, it was widely believed by advertising interests - who consisted of manufacturers of highly advertised products, retailers, publishers, and advertising agents - that untruthful advertising imposed a negative externality on all advertising, and that misleading advertisements were a rottenapple that reduced the credibility of all advertising. False advertising was therefore perceived to be harmful not only to consumers, who might be mislead, but also to other businesses since it reduced the returns to all advertising. Regulation was sought by a broad coalition of producer groups in order to eliminate rotten-apple advertising since the court system could not be easily used by producer and consumer groups who were negatively affected by false advertising. This third hypothesis, like the first two, is also a rent-seeking story in that it involved producers lobbying the state for regulation that

\footnotetext{
${ }^{1}$ It is generally believed that advertising, as a costly signal, serves as a mechanism for solving the asymmetric information problem about product quality. Advertising can reduce the extent of asymmetric information either by serving as a pure signal of quality, or by directly informing consumers about product characteristics. In some theoretical models of advertising (Nelson 1974; Schmalensee 1978; Milgrom and Roberts 1986), because advertising is a sunk cost, only high quality producers have an incentive to advertise in equilibrium. Hence, in these models, the information conveyed by advertising is not important; all that matters is that one advertises. Nelson (1974), among others, finds some empirical evidence in favor of this perspective. In other models, however, advertising may play a directly informative role in helping consumers determine product characteristics (Butters 1977; Grossman and Shapiro 1984). As a result, it is not sufficient that firms advertise; it is also important that the firm's advertising be credible. In a setting where the credibility of advertising is suspect, advertising is unlikely to function effectively as a market mechanism for solving the asymmetric information problem.
} 
would create private benefits, but in this case, rent-seeking by producers also generated benefits for consumers in the way of improved information about product quality.

To test these hypotheses we take advantage of cross-state and temporal variation in the introduction of advertising regulation at the state-level during the early decades of the twentieth century to investigate the causal relationships among advertising regulation, the level of advertising expenditures (a proxy for total investment in advertising by firms), and the composition of advertising expenditures. According to the first hypothesis regulation should reduce the level of investment in advertising. The second hypothesis argues that advertising regulation should shift advertising away from national outlets (magazines) and towards more local outlets (newspapers). The last hypothesis posits that regulation, by improving the credibility of advertising, should increase investment in advertising. We find that state advertising legislation significantly increased the level of real per capita advertising expenditures at the state-level, controlling for other factors. This result survives a variety of robustness checks. We find no evidence that regulation shifted advertising away from magazines and towards newspapers. Finally, we find that the Federal Trade Commission (FTC) Act of 1914 had a more positive effect on real advertising expenditures per capita within states that had already enacted a truth-inadvertising law. We believe this body of evidence supports the third hypothesis because it suggests that regulation increased firms' willingness to invest in advertising.

The remainder of this paper is organized as follows. Section II provides historical background on the rise of advertising in turn-of-the-century America. This is followed in Section III by a discussion of the three competing hypotheses for advertising regulation. 
Section IV presents our empirical evidence. In Section V we demonstrate that our key empirical finding is robust. Section VI concludes.

\section{HISTORICAL BACKGROUND}

Falling transportation costs during the late nineteenth and early twentieth centuries made possible tremendous increases in specialization (Kim 1998, 2000). While specialization increases the gains from trade, specialization also comes at the cost of asymmetric information about product quality. The more specialized individuals are, the less they know about the goods and services produced by others (Wallis and North 1986). As is well known, asymmetric information about product quality can give rise to the "lemons problem" in which low quality goods dominate the market (Akerlof 1970).

Many scholars have noted the role that market mechanisms play in reducing informational asymmetries. Klein and Leffler (1981), for instance, show how nonsalvageable investments in reputation-such as brand name development and advertising — can play a role in signaling quality to consumers. Along these lines, Kim (2001) argues that multiunit firms and retail chains emerged during this time as solutions to this asymmetric information problem. Hence, it is not surprising that this period of rapid specialization also witnessed the widespread use of advertising and the proliferation of brand names. Indeed, it was during this period that a new group of middlemenadvertising agents-emerged, first to negotiate advertising rates with newspapers and magazines on behalf of manufacturers and distributors, and later, to develop more persuasive forms of advertising copy (Pease 1958). 
Obtaining accurate estimates of the growth of advertising is difficult since few sources report systematic data on total advertising volumes in all forms of advertising media. Nevertheless, the available figures do suggest its rapidly growing importance. For instance, according to estimates reported by Borden (1942, p. 48), per capita advertising revenues of periodicals and newspapers in America increased dramatically, from 78 cents per capita in 1899 to over $\$ 5$ per capita in 1919. It would appear that this increase in advertising revenues was not merely due to increases in the price of advertising space, but rather, due to increases in quantities. According to the Printer's Ink General Index of Advertising Activity, advertising volumes (i.e. quantities) approximately doubled between 1914 and 1920 (Borden 1942, p. 57). Within Boston, the total lines of advertising in four major daily newspapers increased from approximately 25 million lines in 1914 to 46 million lines in 1924 (Boston Globe Databook, 1925). Printer's Ink (vol. 88 , no. 7, July $\left.2^{\text {nd }}, 1914\right)$ reports that between 1911 and 1914, the number of agate lines of advertising in sixteen major women's magazines increased from 178,000 to 212,000. Hence, many sources point to significant growth in advertising during this time.

In turn-of-the-century America, most advertising was either by direct mail or in newspapers or magazines. Even by 1935, after the introduction of radio as an alternative medium for advertising, over 40 percent of all advertising was placed in newspapers and magazines and direct mail advertising comprised another 30 percent (Borden 1942, p. 54). Additionally, throughout this period, local advertising in newspapers and magazines constituted approximately 80 percent of all advertising in these media (Pease 1958, p. 14). While information on advertising costs is limited, the available evidence indicates that they were not substantial. Local and national firms advertised widely, as did firms 
producing products of varying qualities. Indeed, products like patent medicines, which were often produced by very small firms, were among the most heavily advertised products (Young 1967; Pope 1983). While the low cost of advertising and the tremendous growth in its volume suggest that business in general found it to be an effective marketing device, reservations were increasingly expressed by a broad coalition of producer interests representing manufacturers, retailers, publishers, and advertising agents, about the truthfulness of advertising copy. From the late 1800s onward, this coalition, which was spearheaded by advertising agents and publishers of newspapers and magazines, began to call for greater monitoring of advertising claims. These concerns were repeatedly expressed in trade publications like Printer's Ink, the most widely distributed advertising journal. $^{2}$

It was in this milieu that the call for truth-in-advertising regulation was born. In the early 1900s, advertising groups like the Association of Advertising Clubs of America (AACA) were formed to encourage advertisers to shun false or misleading advertising and to educate firms about the benefits of truthful advertising. Diverse interests including manufacturers, retailers, publishers, advertising agents, and other parties that had a stake in the quality of advertising, were members of these groups. Important leaders included Samuel Dobbs, sales manager for Coca-Cola, John Romer, editor of Printer's Ink, Joseph Appel, advertising manager for the retail chain John Wanamaker's, and H.J. Kenner, a

\footnotetext{
${ }^{2}$ In fact, the credibility of advertising was one of the most frequently discussed issues among publishers and advertising men of this period (Kenner 1936). It was widely believed by these groups that advertising would be of little value if it were not perceived to be truthful by consumers and that the credibility of all advertising could be challenged by a few, untruthful ads. This sentiment was the official view of the editors of Printer's Ink, the most widely circulated advertising trade periodical. According to Pope (1983, p. 191) Printer's Ink believed that "[O]ne false statement in an advertisement would weaken its effect; one false advertisement would injure a seller's credibility permanently; one discredited advertiser would harm the advertising of all others." In other words, untruthful advertising that misrepresented various dimensions of product quality had the potential to impose a negative externality on all advertising.
} 
former newspaper man and advertising manager (Kenner 1936; Pope 1983; Borden 1942). By 1910, these groups began to urge their members to press for state regulation of advertising. In 1911, Printer's Ink hired H.D. Nims, a New York lawyer, to author a model truth-in-advertising statute which made deceptive advertising a misdemeanor. According to this statute:

Any person, firm, corporation or association who, with intent to sell or in any wise dispose of merchandise, securities, service, or anything offered by such persons, firms, corporations, or associations, directly or indirectly, to the public for sales or distribution, or with the intent to increase the consumption thereof, or to induce the public in any manner to enter into any obligation thereto, or to acquire the title thereto, or an interest therein, makes, publishes, disseminates, circulates, or places before the public, or causes, directly or indirectly to be made, published disseminated, circulated or placed before the public, in the form of a book, notice, handbill, poster, bill, circular, pamphlet or letter or in any other way, an advertisement of any sort regarding merchandise, securities, service or anything so offered the public which advertisement contains, any assertion, representation, or statement of fact, which is untrue, deceptive or misleading, shall be guilty of a misdemeanor (quoted in Roper 1945, p. 291).

This model statute was endorsed by pro-advertising regulation groups and throughout the 1910s and early 1920s the overwhelming majority of state governments enacted some version of it (see Table 1). Enforcement of these laws was largely left to local advertising clubs (which later became known as the Better Business Bureaus or BBBs). These BBBs monitored local advertising, received complaints from consumers and other producers, investigated suspect ads, and used the threat of prosecution under these truth-inadvertising laws to induce compliance on the part of firms (Kenner 1936; Pope 1983). Indeed, because the BBBs were able to threaten misleading advertisers with prosecution under truth-in-advertising regulation, much compliance was achieved without lawsuits. For instance, in Minneapolis in 1917, out of 137 cases investigated by the local bureau, only three resulted in prosecution. In 1920, only six cases were prosecuted out of a total 
of 241 cases investigated (Pannell 2002). For the year ending in May, 1921, only 51 of the 6,815 cases handled by local BBBs throughout the country resulted in prosecution (Printer's Ink, June $16^{\text {th }}, 1921$ ). Although the total number of prosecutions under these state laws was low, the available qualitative evidence indicates that the mere threat of a lawsuit provided the BBBs with the moral authority to correct advertising abuses (Pope 1983; Pease 1958). Indeed, the fact that the constitutionality of state truth-in-advertising legislation was challenged in state courts suggests that the BBBs' efforts to enforce these laws against misleading advertisers were quite effective (Pannell 2002). The constitutionality of these laws, however, was never overturned in state or federal courts. Hence, it would seem that while enforcement of truth-in-advertising regulation was largely informal, it was quite successful.

\section{THREE HYPOTHESES FOR ADVERTISING REGULATION}

It is widely argued that regulation is enacted to confer competitive advantages on certain producers at the expense of overall efficiency. Politically organized producers often seek regulation to reduce the number of firms in a market, limit the availability of substitutes, or to constrain the strategic options available to competing firms. Regulation that serves these purposes increases the profits of certain firms, but generally reduces economic welfare (Stigler 1971, Peltzman 1976). In our view, there are two plausible hypotheses for advertising regulation that are consistent with this perspective.

The first hypothesis argues that truth-in-advertising regulation conferred competitive advantages on producers by collectively limiting the use of advertising as a competitive device. A significant body of evidence demonstrates that the prices of goods 
and services tend to be higher in places that restrict advertising than in places that do not (Benham 1972; Cady 1976; Kwoka 1984). This evidence is sometimes invoked as an explanation for why associations representing doctors, lawyers, and other professional groups often seek regulation that limits advertising. While organized producers like professional associations may be able to obtain advertising regulation specific to their industry, a general truth-in-advertising law has the potential to benefit a broader group of producers, and may be easier to cloak in the "public interest." If truth-in-advertising regulation, by raising the cost of advertising, also succeeded in reducing its extent, firms in many industries might have an incentive to seek such regulation since it would result in less competition and higher retail prices. Under this hypothesis, advertising regulation should shift inward the derived demand for advertising space and reduce the quantity of advertising, other things held constant.

A second hypothesis posits that regulation was desired by a subset of smaller, local producers, who wanted to competitively disadvantage the growth of larger, national brands through the regulation of advertising copy. The early twentieth century witnessed the rise of large, national firms that were able to obtain economies of scale and scope in the production of a wide range of goods and services. Smaller local producers often found themselves at a competitive disadvantage with respect to these larger firms. Statelevel regulations like meat inspection, antitrust, chain store taxes, were often sought by local firms seeking to stem the competitive threat posed by these larger firms (Libecap 1992; Ross 1986). Kim (1999) argues that large, multiunit firms obtained significant economies of scale in marketing and advertising their products. Was truth-in-advertising 
regulation motivated by a desire on the part of small, local firms to limit the competitive advantage enjoyed by larger, national brands?

To evaluate this hypothesis, we examine how advertising regulation affected the composition of advertising volumes. If state-level advertising regulation disadvantaged national brands, we would expect to see the share of advertising by national brands to decline and the share of advertising by local producers to rise. Unfortunately, systematic data on the national versus local composition of advertising is not available. However, we were able to collect advertising revenue data separately for newspapers and magazines. Since magazine advertising was consisted primarily of national brands while local firms dominated newspaper advertising, we can proxy for national and local advertising shares (Pease 1958). Under this second hypothesis, the share of total advertising placed in magazines should decline following the enactment of advertising regulation.

A third hypothesis is that regulation was sought by various interests to eliminate "rotten-apple" advertisements that threatened the credibility of all advertising. According to this hypothesis, advertising regulation was desired as a solution to a negative externality problem caused by a few, misleading advertisements. Because advertising was inexpensive and widely available to most firms, the mere expenditure of resources on advertising was not a reliable signal of quality. In such an environment, much of advertising's value depended on its credibility as a mechanism for conveying information about product characteristics. Misleading advertisements that reduced the credibility of advertising were perceived to be harmful not only to consumers but also to other businesses, since they reduced the value of advertising as a marketing device. ${ }^{3}$

\footnotetext{
${ }^{3}$ Printer's Ink argued that "[i]f every newspaper advertisement were strictly legitimate, the returns from advertising would show a marked improvement." (Printer's Ink, $11^{\text {th }}$ April 1894, p. 432). Advertising
} 
Regulations that made it more costly to place misleading or untruthful advertisements were desired to eliminate this negative externality. ${ }^{4}$

A refutable implication of the rotten-apple hypothesis for advertising regulation is that regulation should improve the credibility of advertising. It is not possible to directly measure the credibility or truthfulness of advertising in an objective fashion. However, we can indirectly infer the effect of regulation on the credibility of advertising by examining the relationship between regulation and the level of investment in advertising. If regulation improves the credibility of advertising, it should increase the returns to advertising, shift outward the derived demand for advertising space, and increase the quantity of advertising, other things equal.

\section{EMPIRICAL ANALYSIS}

\section{A. Effects of state-level advertising regulation}

The three hypotheses outlined make different predictions regarding the relationship between advertising regulation and the quantity of advertising. The testable implication of the first hypothesis is that regulation limits competition and reduces the

industry executives apparently believed that untruthful advertising was a negative externality for all advertising. While certain retailers and publishers attempted to self-censor their advertising copy (Pope 1983, p. 188), it soon became clear that it was costly for any individual business to improve the credibility of its own advertising. First, for publishers, forgone advertising revenues were substantial. Earnings from advertising constituted an increasingly large percentage of total newspaper and magazine revenues. Officials from Good Housekeeping magazine estimated that their losses from refusing to print suspect advertising exceeded a million dollars between 1912 and 1930 (Pease 1958, p. 82). Second, for many products like patent medicines, foods, textiles, and furniture, the benefits of short-term deception about product quality were large (Young 1967; Watkins 1940). For these reasons, trade associations were generally unwilling to discipline their members for misleading advertisements. Self-censure at the firm or industry level was therefore not a viable solution.

${ }^{4}$ The potential to be sued in the courts for selling defective products to customers should also discipline firms. However, during the Progressive Era, the courts generally did not protect the rights of consumers who were harmed by producers. Glaeser and Shleifer (2003), for instance, argue that the disproportionate influence of large business during the Progressive Era made the court system an unsuitable arena for resolving disputes between consumers and firms. 
level of advertising. According to the second hypothesis, regulation shifts advertising away from national media (magazines) and towards local media (newspapers). The third hypothesis argues that regulation, by improving the credibility of advertising, increases the level of advertising. In this section, we take advantage of cross-state and temporal variation in the adoption of state-level truth-in-advertising regulation to test these hypotheses. Our data consists of a balanced panel of state-year observations taken from the $1899,1909,1914,1919,1923$ and 1929 manufacturing censuses.

To test these hypotheses we examine the effects of advertising regulation on the level and composition of advertising revenues. Ideally, we would like to analyze the impact of regulation on the quantity of advertising placed by producers and retailers. Although we do not have systematic data on advertising quantities, for our purposes, it is sufficient to examine the effect of regulation on advertising revenues. ${ }^{5}$ Holding constant the supply curve for advertising space, an inward shift in the derived demand for advertising space should reduce the quantity of advertising and total advertising revenues, and an outward shift in the derived demand should increase both the quantity of advertising and total advertising revenues. Hence, we can identify changes in quantities by examining changes in revenues.

This seems like a plausible empirical framework. This is because truth-inadvertising laws made it more costly for manufacturers and retailers to advertise but they did not make it more costly for publishers to print false advertisements. In fact, in many states, publishers were explicitly exempted from liability under the law. In other words, the laws targeted the demanders of advertising space (manufacturers and retailers), not

\footnotetext{
${ }^{5}$ Various sources including Ayers and Printer's Ink report some data on the number of agate lines of advertising in selected newspapers and magazines. Unfortunately these data sets did not overlap sufficiently with the period under investigation to be useful for our regression analysis.
} 
the suppliers of advertising space (publishers and advertising agents). This implies that regulation should affect the derived demand for advertising space, but not the supply.

Unfortunately, data on total advertising revenues across all forms of advertising media by firms or by states are not available in this period. However, we do have census data on the advertising revenues of newspapers and magazines in each state in each census year. We believe this is a reasonable proxy for the volume of advertising during this time, as print media earned the largest portion of total advertising revenues. ${ }^{6}$

The primary outcome variable we examine is the level of real advertising revenues per capita at the state-year level. ${ }^{7}$ In order to make valid causal inferences about the effect of advertising legislation on advertising expenditures, we need to establish that the timing of regulation was exogenous with respect to other factors that may have influenced the level of advertising. In particular, we are concerned that states that adopted advertising regulation earlier were also states where advertising was more prevalent. To investigate this possibility, we estimated Weibull hazard regressions that explain the timing of state truth-in-advertising laws as a function of time invariant state-level conditions before the introduction of advertising regulation (see Table A1 in the Appendix). The hazard regressions indicate that the level of advertising per capita in 1909 did not have a statistically significant influence on the timing of advertising legislation. The coefficients on urbanization, manufacturing per capita, and income per capita are statistically significant, but especially for manufacturing and income per capita,

\footnotetext{
${ }^{6}$ Henceforth we use the terms advertising expenditures and advertising revenues interchangeably. By definition total expenditures by firms on advertising in newspapers and magazines must equal total advertising revenues earned by newspapers and magazines.

${ }^{7}$ We divided total advertising expenditures by state population to normalize for differences in market size across states and converted these figures to real 1967 dollars using CPI. We could not control more directly for market size using circulation data because circulation figures were not reported consistently across the various manufacturing censuses.
} 
the hazard ratio is close to unity. Accordingly, we will also control directly for these factors when we examine the effects of regulation on advertising. Two of the variables that measure Progressive reform sentiment are also significant. It appears that states with higher Progressive vote shares in 1912 and states that enacted civil service merit reform before 1909 were more likely to be early adopters of regulation. By including state and year fixed effects in our empirical model of the effects of regulation on advertising, we can control for state specific factors like political sentiment that evolve similarly across all states over time. In this framework, identification of the effects of regulation on advertising comes from within-state variation in advertising revenues.

Our basic regression model is as follows:

$$
y_{i t}=\alpha+\beta R_{i t}+X_{i t} \gamma^{y}+T_{t}+S_{i}+\varepsilon_{i t}
$$

where $y_{i t}$ is the outcome variable (either real per capita advertising expenditures or the share of total advertising revenues placed in magazines), $R_{i t}$ is an indicator variable that equals 1 if a state has adopted regulation by a given census year and 0 otherwise, $X_{i t}$ is a vector of state-year control variables, $T_{t}$ are year fixed-effects, $S_{i}$ are state fixed-effects and $\varepsilon_{i t}$ is an error term. The coefficient of interest is $\beta$, which shows the effect of regulation on the outcome variable. As control variables we include real per capita income, the urbanization rate, and the level of real manufacturing per capita since they are likely correlated with the level of economic development within a state and the extent of advertising. ${ }^{8}$ Descriptive statistics are displayed in Table 2.

\footnotetext{
${ }^{8}$ We also estimated our regressions controlling specifically for those manufacturing industries (such as patent medicines, confectioneries, tobacco and prepared foods) that advertised heavily during this period. Controlling for manufacturing in this way did not change the sign or significance of the relationship between state-level advertising regulation and advertising.
} 
Columns (1) and (2) of Table 3A show the effects of advertising regulation on the level of real per capita advertising expenditures in newspapers and magazines. The coefficient on the advertising regulation indicator is positive and statistically significant in both specifications. The coefficient estimates indicate that the introduction of advertising regulation increased the value of real advertising expenditures per capita by approximately 80 cents, which represents an increase of 10 percent above the average level during this period. This is an economically significant magnitude. These preliminary results are supportive of the rotten-apple hypothesis, which posits a positive relationship between regulation and the level of advertising, and are inconsistent with the first hypothesis, which argues that regulation should reduce advertising.

While our fixed-effect framework controls for state-specific political tastes that change similarly across all states, it is possible that liberal reform sentiment evolved differently in different places. Our solution to this problem is to include indicator variables for Progressive Era reforms like civil service merit reform, the presence of initiative and referenda, direct primaries, and child labor laws that were adopted at different times in different states. The regressions displayed in Table 3B include statelevel indicators of Progressive Era reform measures as additional control variables. We find no statistically significant correlation between these Progressive Era reform measures and the level of advertising expenditures per capita. Additionally, the sign, statistical significance, and magnitude of the relationship between advertising regulation and the level of per capita advertising expenditures survive the inclusion of these variables. 
A potential problem with the regulation indicator variable that we are using is that it treats all states that regulated advertising as having the same regulatory regime. In order to reduce this possible source of measurement error we take advantage of information about the nature of state advertising laws. In particular, we create an alternative regulation indicator variable that equals 1 if the state introduced a strict advertising law that did not require the prosecution to prove intent to defraud and 0 otherwise. Coding the advertising regulation variable in this way may reduce measurement error arising from the fact that the ability of state and local officials to enforce regulation may have depended on the standard of proof required for a successful prosecution. Columns (3) and (4) in Table 3A display the regression results using this alternative measure of regulation. We continue to find a positive and statistically significant relationship between advertising regulation and the level of real per capita advertising. The magnitude of this effect is similar as well. As shown in column (2) of Table 3B this result is also robust to the inclusion of state-specific Progressive reform measures.

The evidence presented so far is consistent with the third hypothesis, which argues that regulation should increase advertising, but not supportive of the first, which posits that regulations should reduce advertising. As a test the second hypothesis, we examined the relationship between advertising regulation and the share of total print advertising in national magazines since the second hypothesis argues that regulation shifted the composition of advertising revenues away from national and toward local outlets. Table 4A displays regressions where the dependent variable is the share of total advertising in magazines. The coefficient on the regulation indicator variable is never 
statistically significant, indicating that advertising regulation did not influence the composition of advertising revenues These results are unaffected by how we measure advertising regulation. In addition, the regression results reported in Table $4 \mathrm{~B}$ show that the level of per capita real advertising revenues in magazines was also unaffected by truth-in-advertising regulation. Hence, to the extent that our dependent variable proxies for the share of national brand advertising, these regression results are not supportive of the second rent-seeking hypothesis which argues advertising regulation reduced competition from national brands. ${ }^{9}$

\section{B. Effects of the Federal Trade Commission Act of 1914}

In 1914 the US federal government enacted the Federal Trade Commission Act, which created the FTC as a regulatory agency. Although this act gave the commission broad authority over various aspects of competition, it did not specifically mention advertising until the Wheeler-Lea Amendment of 1938. Nevertheless, the FTC soon became interested in fraudulent advertising because of its authority to regulate unfair and deceptive selling practices. Shortly after its creation, the FTC met with state and local advertising clubs about the problem of misleading advertising and began to coordinate its enforcement efforts with state and local officials (Watkins 1940). An important question for us is what additional effect enforcement of the FTC Act may have had on advertising.

We can analyze the effect of the FTC Act on advertising by taking advantage of the two facts. The first is that the FTC Act provided state authorities and Better Business Bureau's with an additional lever to enforce truth-in-advertising regulation. The FTC Act

\footnotetext{
${ }^{9}$ Qualitative evidence also does not suggest that local firms or state authorities used truth-in-advertising regulation to prosecute the producers of larger, national brands. An examination of state court cases during the period from 1910 to 1930 revealed very few prosecutions under these statutes. Among those few prosecutions, it did not seem that large national brands were being targeted in any systematic way.
} 
enhanced state-level enforcement capabilities because it gave groups involved in the enforcement of state laws with an additional "stick" with which to enforce truth-inadvertising regulation, particularly with respect to firms involved in interstate trade; statelevel regulations could not be easily applied to firms engaged in interstate commerce. The second is that, by 1914 , some, but not all, states had already enacted a truth-in-advertising law. Enforcement of advertising regulation was likely better organized in early adopting states than in later adopting states. Cooperation between the FTC and state-level enforcement organizations was therefore more likely to occur in early than late adopting states. Accordingly, by comparing the effect of the law on states that had already enacted advertising legislation by 1914 (where enforcement was better organized) with those states that had not enacted a law by 1914 (where enforcement was more fledgling), we can use a difference-in-differences estimator (DID) to determine the effect of the FTC on advertising.

In order to make valid causal inferences about the additional effect of the FTC Act on advertising, we need to establish that the Act was exogenous with respect to advertising. We are confident that this is in fact the case. First, the historical literature does not suggest that advertising interests played any role in the enactment of the FTC Act (Watkins 1940). Indeed, it is noteworthy that the legislation creating the FTC never mentioned advertising explicitly; the FTC's interest in regulating advertising was an unintended outcome of the 1914 law. Second, logistic regression analysis of Senate voting on the bill that became the FTC Act shows no statistically significant relationship between measures of advertising interest at the state-level and the likelihood a Senator from a given state voted in favor of the bill. As shown in Table A2 in the Appendix, 
neither the per capita value of advertising in 1909 nor the presence of a state-level truthin-advertising law by 1914 has a statistically significant relationship with Senate voting on the FTC bill. The first dimension D-Nominate score (which measures a legislator's ideology over economic issues) and the Republican Party indicator are the only variables that are statistically significant determinants of Senate voting on the FTC bill across various regression specifications. Accordingly, we believe that a DID estimator will yield valid causal inferences about the additional effect of the FTC Act on advertising.

The DID regression equation is as follows:

$$
y_{i t}=\alpha+\beta R_{i t}+\delta F T C_{t}+\phi\left(R_{i t}\right)\left(F T C_{t}\right)+X_{i t} \gamma+T_{t}+S_{i}+\varepsilon_{i t}
$$

where $R_{i t}$ is an indicator variable that equals $l$ if a state had adopted regulation prior to 1914 and 0 otherwise, FTC is an indicator variable that equals 1 for all years in which the FTC Act is in effect and 0 otherwise, and the other variables are defined as before. The coefficient of interest in this regression is $\phi$, the coefficient on the interaction term. This coefficient shows the additional effect that the FTC Act had on the outcome variable (either real per capita advertising expenditures or the share of total advertising in magazines) in states that enacted an advertising law prior to 1914.

Columns (1) and (2) display the regression estimates when the level of advertising per capita is the dependent variable. The coefficient on the interaction term is positive and significant in both regressions, suggesting that the FTC Act increased advertising by more in those states that were early adopters of advertising regulation. This result is consistent with the third hypothesis but inconsistent with the first hypothesis. In columns (3) and (4) the dependent variable is the share of magazine advertising. We find no evidence that the FTC Act shifted the composition of advertising away from magazines 
and towards newspapers by more in those states that were early adopters of regulation. In fact, the regression reported in column (4) suggests that the FTC Act may have shifted advertising toward magazines. Although not displayed, we also find no evidence that the FTC Act reduced the level of per capita magazine advertising in early adopting states. Our DID analysis of the effect of the FTC Act therefore furnishes additional support for the rotten-apple story which argues that advertising regulation, by improving the credibility of advertising, increased advertising volumes. ${ }^{10}$

\section{ROBUSTNESS TESTS}

Our primary finding is that state-level advertising regulation had a positive and statistically significant effect on the level of advertising expenditures per capita. This result survives the inclusion of different control variables as well as the use of different measures of advertising regulation. Additionally, hazard regression analysis of the adoption of state-level advertising regulation indicates that these laws were not more likely to be introduced more quickly in those states where advertising was more prevalent, which allows us to rule out a potential endogeneity problem. In this section, we present a variety of additional robustness tests that help us establish that this relationship between regulation and per capita advertising expenditures is in fact causal.

First, we show that placebo (i.e. accelerated) truth-in-advertising laws do not affect the level of per capita advertising. The placebo advertising regulation variable is constructed by coding a state as having introduced advertising regulation five years

\footnotetext{
${ }^{10}$ Evidence from FTC caseloads is also supportive of this view. According to information presented in Watkins (1940), by 1919, over 11 percent of the FTC's caseload was related to product misrepresentation, and this share increased dramatically over the next decade. Hence, passage of the FTC Act may have had some effect on the credibility of advertising.
} 
before it actually introduced regulation. For instance, if Kentucky enacted an advertising law in 1917, the placebo regulation variable codes Kentucky as having introduced a law in 1912. If the coefficient on the placebo regulation indicator is non-zero, then there is a good chance that our estimates using the true (non-placebo) regulation indicator are biased. This would suggest that the true advertising regulation variable is picking up some other trend in the data. On the other hand, if the placebo regulation variable is insignificantly different from zero, we have more faith that the true advertising regulation variable is capturing the actual effect of the law.

Table 6A shows the regression results using the placebo regulation indicator. The regression equations reported in this table are identical to those reported in Table 3A, except that the placebo advertising regulation indicator replaces the true advertising regulation indicator. The coefficient on the placebo regulation indicator is never statistically significant. This suggests that advertising regulation did in fact have a positive and statistically significant effect on real advertising expenditures per capita.

We also coded regulation as having been enacted five years after the true enactment of a truth-in-advertising law. For example, if Kentucky enacted an advertising law in 1917, our delayed truth-in-advertising regulation variable codes Kentucky as having introduced a law in 1922. While the placebo (accelerated) regulation indicator should have no effect on advertising expenditures per capita, the delayed regulation indicator should have a statistically significant effect. Indeed, we might expect to observe an even larger effect using the delayed regulation indicator than the true regulation indicator because regulation may take time to have an impact on the advertising industry. Table 6B shows the results using the delayed regulation indicator. As expected, the 
coefficients on these indicators are positive and statistically significant and, interestingly, they are also larger in magnitude than the coefficients on the true advertising regulation indicator reported in Table 3A.

As an additional robustness check, we re-estimated our regressions using real tax revenues per capita as an alternative outcome variable. Clearly, advertising regulation should not have a positive effect on tax revenues per capita. A positive and significant relationship between advertising regulation and tax revenues per capita would suggest that our original regressions are spurious, and that our advertising regulation variable is picking up an omitted factor, perhaps liberal political sentiment that is positively correlated with advertising, the size of government, and the propensity to regulate. The regressions using tax revenues per capita as the outcome variable are shown in Table 7. The coefficient on the advertising regulation indicator variable is either not statistically significant, or negative and significant. This provides additional evidence that our key findings are not spurious.

In each of our key regressions, the coefficient on manufacturing per capita is positive and significant. Advertising per capita and manufacturing per capita are therefore highly correlated. A possible concern is that both variables are simply proxies for the level of economic development. If more economically developed states are also more likely to regulate industry, then our regressions will overestimate the effect of advertising regulation. To rule out this possibility, we examined the relationship between advertising regulation and the value of manufacturing per capita. The regressions displayed in Table 8 show that advertising regulation had no effect on the level of manufacturing per capita 
at the state-level. Accordingly, we do not believe that simultaneity of this kind is a concern.

\section{CONCLUSION}

During the late $1800 \mathrm{~s}$ and early 1900s, specialization, growing product sophistication, and the rise of impersonal exchange created a role for advertising as a mechanism through which producers could communicate aspects of product quality to consumers. In a world where consumers knew less and less about the products they were purchasing, advertising furnished an efficient medium through which producers could communicate aspects of product quality to consumers. Hence, it is not surprising that this period of rapid technological and organizational change also witnessed a dramatic increase in the volume of advertising.

The value of advertising as a communication device was well understood by a coalition of producers, retailers, and publishers. Indeed, these groups quickly perceived that the usefulness of advertising would be undermined if advertising was believed to be misleading or deceptive, and they argued that false advertising by one advertiser had the potential to undermine the credibility of all advertising. Thus, advertising interests organized rapidly to curb misleading and untruthful advertising through government regulation.

In this paper we present evidence that suggests that truth-in-advertising regulation was indeed sought by advertising interests in an effort to stem the negative effects of misleading advertising. We find that the data do not support the two most plausible alternative explanations for advertising regulation. In particular, we find that truth-in- 
advertising regulation did not reduce the extent of advertising overall nor did it shift the composition of advertising in ways that benefited local firms. This suggests that advertising regulation did not function as an anti-competitive device that either limited competition directly or hampered the growth of national brands. Instead, we uncover a robust positive and statistically significant effect of regulation on advertising expenditures in newspapers and magazines. We interpret these results as supportive of the rotten-apple hypothesis, which argues that regulation, by improving the credibility of advertising, should increase overall investment in advertising. ${ }^{11}$

We believe this study complements and contributes to a growing literature on the nature of Progressive Era regulation. Recent studies of Progressive Era reform indicate that broader coalitions in favor of regulation increase the likelihood that regulation will be adopted (Fishback and Kantor 1998; Law 2003; Mahoney 2003). In the context of truth-in-advertising regulation, a broad coalition of business interests sought advertising regulation and, as shown in Table 1, regulation diffused across states very quickly. In addition, while studies of Progressive Era regulations like chain store taxes, meat inspection, and "blue sky laws" suggest that many regulations were enacted to tilt the

\footnotetext{
${ }^{11}$ The rotten-apple story for advertising regulation is also better able to account for the nature of the political constituency in favor of regulation than the other two hypotheses. The key players in the push for advertising regulation were publishers and advertising agents. Publishers and advertising agents would clearly be most affected by regulation that improves the credibility of advertising. Broad regulation aimed at improving the perceived credibility of advertising across the board would presumably increase the earnings of publishers and advertising agents if in fact misleading advertising was a "rotten apple" that reduced the returns to advertising overall. While producers and retailers might benefit from a reduction in the extent of competition brought about by advertising regulation that limits the amount of advertising or changes the composition of advertising, publishers and advertising agents certainly would not. In fact, in the late 1800 s and early 1900s, earnings from advertising constituted an increasingly large percentage of total newspaper and magazine revenues. Advertising revenues as a share of total newspaper and magazine earnings increased from 44 percent in 1880 to 65 percent in 1920 (US Bureau of the Census 1880, 1920). Publishers and advertising agents would probably have opposed regulation that reduced these revenues. Thus, it seems unlikely that publishers and advertising agents would find it in their interests to support advertising regulation that reduced the extent of advertising.
} 
competitive playing field in ways that benefited specific producer groups (Ross 1986; Libecap 1992; Mahoney 2003), another set of studies finds that other Progressive Era regulations, specifically those related to food, drugs, and professional quality, were primarily motivated by a desire to reduce informational asymmetries, and only secondarily, to tilt the competitive playing field through the introduction of entry barriers (Law 2003; Law and Kim 2005; Law and Libecap 2005). In these instances of relatively more benign regulation, producer interests were usually the most important supporters of reform, but consumers also benefited from regulation. Our account of the history of truth-in-advertising regulation appears to be more consistent with this second set of studies. Although business interests were the key constituencies in favor of truth-inadvertising regulation, it would not appear that consumers were harmed. Indeed, to the extent that these regulations succeeded in improving the credibility of advertising, consumers may have also benefited. Truth-in-advertising regulation therefore furnishes an example of successful Progressive Era regulation in that it was adopted rapidly and may have generated important benefits for both consumers and producers. 


\section{REFERENCES}

Akerlof, George (1970). "The Market for 'Lemons': Quality University and the Market Mechanism.” Quarterly Journal of Economics 84: 488-500.

Benham, Lee (1972). "The Effect of Advertising on the Price of Eyeglasses." Journal of Law and Economics 15: 337-52.

Borden, Neil H. (1942). The Economic Effects of Advertising. Chicago: Richard D. Irwin Inc.

Butters, Gerard R. (1977). "Equilibrium Distribution of Sales and Advertising Prices." Review of Economic Studies 44: 465-91.

Cady, John F. (1976). "An Estimate of the Price Effects of Restrictions on Drug Price Advertising." Economic Inquiry 14: 493-510.

Darby, Michael and Edward Karni (1973). "Free Competition and the Optimal Amount of Fraud." Journal of Law and Economics 16: 67-88.

Fishback, Price and Shawn Kantor. (1998). "The Adoption of Workers Compensation in the United States." Journal of Law and Economics 41: 305-41

Fishback, Price and Shawn Kantor (2000). A Prelude to the Welfare State: The Origins of Workers' Compensation. Chicago: University of Chicago Press.

Gilligan, Thomas, William Marshall and Barry Weingast (1989). "Regulation and the Theory of Legislative Choice: The Interstate Commerce Act of 1887." Journal of Law and Economics 32: 35-61.

Glaeser, Edward and Andrei Shleifer (2003). "The Rise of the Regulatory State." Journal of Economic Literature 41: 401-25.

Grossman, Gene M. and Carl Shapiro (1984). "Informative Advertising with Differentiated Products." Review of Economic Studies 51: 63-81

Kenner, H. J. (1936). The Fight for Truth in Advertising. New York: Round Table Press.

Kim, Sukkoo (1998). “Economic Integration and Convergence: US Regions, 1840-1987”. Journal of Economic History 58: 659-83.

Kim, Sukkoo (1999). "The Rise of Multiunit Firms in U.S. Manufacturing.” Explorations in Economic History 36: 360-86.

Kim, Sukkoo (2000). "Urban Development in the United States, 1690-1900." Southern Economic Journal 66: 855-80. 
Kim, Sukkoo (2001). "Markets and Multiunit Firms from an American Historical Perspective." Advances in Strategic Management 18: 305-26.

Klein, Benjamin and Keith Leffler (1981). "The Role of Market Forces in Assuring Contractual Performance.” Journal of Political Economy 89: 615-41.

Kolko, Gabriel (1963). The Triumph of Conservatism: A Reinterpretation of American History, 1900-1916. New York: Macmillan.

Kuznets, Simon and Dorothy Brady (eds.) (1965). Population Redistribution and Economic Growth: United States 1870-1950. Philadelphia: American Philosophical Society.

Kwoka, John E. (1984). "Advertising and the Price and Quality of Optometric Services." American Economic Review 74: 211-16.

Lamb, Ruth (1936). An American Chamber of Horrors: The Truth About Food and Drugs. New York: Arno Press.

Law, Marc T. (2003). "The Origins of State Pure Food Regulation." Journal of Economic History 63 (4): 1103-1130.

Law, Marc T. and Gary D. Libecap (2006). "The Determinants of Progressive Era Reform: The Pure Food and Drugs Act of 1906." In Glaeser, Edward and Claudia Goldin (eds.). Corruption and Reform: Lessons from America's History. Chicago: University of Chicago Press, 319-42.

Law, Marc T. and Sukkoo Kim (2005). Specialization and Regulation: The Rise of "Professionals" and the Emergence of Occupational Licensing Regulation." Journal of Economic History 65 (3): 723-56.

Libecap, Gary (1992). "The Rise of the Chicago Packers and the Origins of Meat Inspection and Antitrust." Economic Inquiry 30 (2): 242-62.

Mahoney, Paul (2003). "The Origins of Blue Sky Laws: A Test of Competing Hypotheses." Journal of Law and Economics 46 (1): 229-51.

Milgrom, Paul and John Roberts (1986). "Price and Advertising Signals of Product Quality." Journal of Political Economy 94: 796-821.

Nelson, Philip (1974). “Advertising as Information.” Journal of Political Economy 82: 311-29.

Pannell, Kerry Ellen (2002). "Origins of the Better Business Bureau: A Private Regulatory Institution in the Progressive Era." Unpublished manuscript. 
Pease, Otis (1958). The Responsibilities of American Advertising: Private Control and Public Influence 1920-1940. New Haven: Yale University Press.

Peltzman, Sam (1976). "Toward a More General Theory of Regulation." Journal of Law and Economics 19: 211-240.

Pope, Daniel (1983). The Making of Modern Advertising. New York: Basic Books.

Printers' Ink. Various volumes and issues.

Roper, Burt (1945). State Advertising Legislation. New York: Printer's Ink Publishing.

Ross, Thomas W. (1986). "Store Wars: The Chain Tax Movement." Journal of Law and Economics 29: 125-37.

Schmalensee, Richard (1978). "A Model of Advertising and Product Quality." Journal of Political Economy 86: 485-503.

US Bureau of the Census (various years). Census of Manufactures. Washington, DC: Government Printing Office.

US Bureau of the Census (various years). Census of Population. Washington, DC: Government Printing Office.

US Department of Commerce (1976). Historical Statistics of the United States: From Colonial Times to the Present. Washington, DC: Government Printing Office.

Wallis, John and Douglass North (1986). "Measuring the Transaction Sector of the American Economy, 1870-1970." In Engerman, Stanley and Robert Gallman (eds.). Long Term Factors in American Economic Growth. Chicago: University of Chicago Press, pp. 95-148.

Watkins, Myron W. (1940). Public Regulation of Competitive Practices in Business Enterprise. New York, NY: Conference Board.

Young, James Harvey (1967). The Medical Messiahs: A Social History of Health Quackery in Twentieth Century America. Princeton: Princeton University Press. 
Table 1: Adoption of truth-in-advertising regulation by year

\begin{tabular}{|c|c|}
\hline Year & States enacting regulation \\
\hline 1912 & Massachusetts $^{\mathrm{a}, \mathrm{c}}$ \\
\hline 1913 & $\begin{array}{l}\text { Connecticut }^{\mathrm{b}, \mathrm{c}}, \operatorname{Iowa}^{\mathrm{c}}, \operatorname{Indiana}^{\mathrm{c}}, \text { Michigan }^{\mathrm{c}} \text {, Minnesota, North Dakota, } \\
\text { Nebraska, New Jersey, Ohio, Pennsylvania }{ }^{\mathrm{a}, \mathrm{c}} \text {, South Dakota }{ }^{\mathrm{a}}, \text { Utah }^{\mathrm{a}} \text {, } \\
\text { Washington }^{\mathrm{c}} \text {, Wisconsin }\end{array}$ \\
\hline 1914 & Louisiana, Maryland ${ }^{\mathrm{a}}$, Rhode Island \\
\hline 1915 & $\begin{array}{l}\text { Alabama, California }{ }^{\mathrm{a}} \text {, Colorado }{ }^{\mathrm{c}} \text {, Idaho, Illinois, Kansas }{ }^{\mathrm{c}}, \text { Missouri }^{\mathrm{c}} \text {, } \\
\text { Montana }^{\mathrm{a}} \text {, North Carolina } \\
\text { Virgina }^{\mathrm{a}} \text {, New York }\end{array}$ \\
\hline 1916 & Virginia \\
\hline 1917 & Kentucky, Oregon $^{\mathrm{c}}$, Wyoming ${ }^{\mathrm{c}}$ \\
\hline 1919 & Arizona $^{\mathrm{a}}$ \\
\hline 1921 & Texas $^{\mathrm{a}}$ \\
\hline 1924 & South Carolina ${ }^{\mathrm{a}}$ \\
\hline 1925 & New Hampshire ${ }^{a}$ \\
\hline 1927 & Florida $^{\mathrm{a}}$ \\
\hline 1931 & Vermont ${ }^{\mathrm{a}}$ \\
\hline After 1931 & Maine, Nevada \\
\hline
\end{tabular}

${ }^{a}$ Denotes that the law required that the intent to defraud the consumer be proven for successful prosecution. States without a superscript did not require fraud to be proven to successfully prosecute misleading advertising

${ }^{\mathrm{b}}$ For New York and Connecticut, the law initially required that the intent to defraud the consumer be proven, but this was later changed in 1921 and 1923, respectively, to require only that the consumer be deceived.

${ }^{\mathrm{c}}$ Indicates that publishers were exempted from liability.

Notes: Information on the year in which legislation was adopted is taken from the State Session Reports for the various states. Information on whether fraud needs to be proven was taken from Roper (1945). 
Table 2: Descriptive statistics

\begin{tabular}{lccc}
\hline Variable & Mean & Std. Dev. & $N$ \\
\hline $\begin{array}{l}\text { Real per capita advertising } \\
\text { expenditures }\end{array}$ & 7.34 & 5.61 & 288 \\
$\begin{array}{l}\text { Real per capita magazine } \\
\text { advertising expenditures }\end{array}$ & 1.28 & 2.38 & 240 \\
$\begin{array}{l}\text { Magazine share of total } \\
\text { advertising expenditures }\end{array}$ & 0.16 & 0.22 & 240 \\
$\begin{array}{l}\text { Real per capita } \\
\text { manufacturing value }\end{array}$ & 310.31 & 236.29 & 288 \\
$\begin{array}{l}\text { Real per capita income } \\
\begin{array}{l}\text { Urbanization percent } \\
\text { Advertising regulation }\end{array}\end{array}$ & 1260.52 & 506.37 & 288 \\
$\begin{array}{l}\text { indicator } \\
\text { Strict } \text { advertising } \\
\text { regulation indicator }\end{array}$ & 0.45 & 21.01 & 288 \\
\hline
\end{tabular}

Notes: Data on advertising and the manufacturing are from the Census of Manufactures (1899, 1909, 1914, 1919, 1923 and 1929). Urbanization rates were taken from Census of Population (1899, 1909, 1919, and 1929). Per capita real income values are from Kuznets and Brady (1965). Urbanization values for 1914 and 1923 and per capita income values for 1909, 1914 and 1923 were linearly interpolated. Data on advertising regulation are constructed from State Session Reports and Roper (1945). Sample sizes for magazine advertising expenditures and shares are smaller because these figures were not available in the 1899 Census. 
Table 3A: Effect of state advertising regulation on advertising expenditures per capita

Dependent Variable: Real per capita advertising (in newspapers and magazines)

\begin{tabular}{lcccc}
\hline & $(1)$ & $(2)$ & $(3)$ & $(4)$ \\
\cline { 2 - 5 } Advertising regulation & $0.84^{* *}$ & $0.81^{* *}$ & & \\
& $(0.41)$ & $(0.39)$ & $1.08^{*}$ & $0.80^{*}$ \\
Strict advertising regulation & & & $(0.59)$ & $(0.48)$ \\
& & & -0.009 \\
Urbanization & & -0.01 & & $(0.05)$ \\
& & $(0.05)$ & & $0.004^{* * *}$ \\
Real income per capita & & $0.004^{* * *}$ & & $(0.001)$ \\
& & $(0.001)$ & & $0.009^{* * *}$ \\
Manufacturing per capita & & $0.009^{* * *}$ & & $(0.002)$ \\
& & $(0.002)$ & 0.87 & 0.89 \\
Adjusted $\mathrm{R}^{2}$ & 0.86 & 0.89 & $0.87 * 7^{* * *}$ \\
F-statistic & $37.41^{* * *}$ & $35.47^{* * *}$ & $33.05^{* * *}$ & $36.32^{* * *}$ \\
$\mathrm{~N}$ & 288 & 288 & 288 & 288 \\
\hline
\end{tabular}

Table 3B: Does the inclusion of political reform variables influence the effect of advertising legislation on advertising expenditures per capita?

Dependent Variable: Real per capita advertising (in newspapers and magazines)

\begin{tabular}{lcc}
\hline & $(1)$ & $(2)$ \\
\cline { 2 - 3 } Advertising regulation & $0.79^{* *}$ & \\
Strict Advertising regulation & $(0.40)$ & $0.96^{*}$ \\
& & $(0.53)$ \\
Civil service merit reform & 0.54 & 1.70 \\
& $(1.14)$ & $(1.14)$ \\
Initiative and referenda & 0.30 & -0.02 \\
& $(0.47)$ & $(0.49)$ \\
Direct primaries & -0.37 & -0.29 \\
& $(0.39)$ & $(0.41)$ \\
Child labor reform & -0.41 & -0.54 \\
& $(0.46)$ & $(0.59)$ \\
Adjusted $\mathrm{R}^{2}$ & 0.90 & 0.88 \\
F-statistic & $33.44^{* * *}$ & $34.52^{* * *}$ \\
$\mathrm{~N}$ & 288 & 288 \\
\hline
\end{tabular}

State and year fixed effects for 1899, 1909, 1914, 1919, 1923 and 1929 are included in the estimation. Robust-standard errors are reported in parentheses. Significance at the 10, 5, and 1 percent levels are denoted by $*, * *$, and $* * *$ respectively. Advertising regulation is a binary variable that equals 1 if a state had enacted a truth-in-advertising law by a certain census year. Strict advertising regulation is a binary variable that equals 1 if a state had enacted a strict version of the truth-in-advertising law. We define a strict law as one that did not require the prosecution to prove intent to mislead. Other covariates in Table 3B include real income per capita, real manufacturing per capita and the level of urbanization. 
Table 4A: Effect of advertising regulation on the share of magazine advertising

Dependent Variable: Share of advertising expenditures in national magazines

\begin{tabular}{lcccc}
\hline & $(1)$ & $(2)$ & $(3)$ & $(4)$ \\
\cline { 2 - 5 } Advertising & 0.003 & 0.006 & & \\
regulation & $(0.02)$ & $(0.02)$ & -0.02 & -0.02 \\
Strict advertising & & & $(0.03)$ & $(0.03)$ \\
regulation & & & -0.001 \\
Urbanization & & $(0.001)$ & $(0.001)$ \\
& & $6.0 \times 10^{-5}$ & & $7.0 \times 10^{-5}$ \\
Real income per & & $\left(6.0 \times 10^{-5}\right)$ & & $7.0 \times 10^{-5}$ \\
capita & $5.0 \times 10^{-5}$ & & $5.0 \times 10^{-5}$ \\
Manufacturing per & & $\left(7.0 \times 10^{-5}\right)$ & & $\left(7.0 \times 10^{-5}\right)$ \\
capita & & 0.81 & & 0.81 \\
& & & 0.81 & $27.07 * * *$ \\
Adjusted $\mathrm{R}^{2}$ & 0.81 & $27.67^{* * *}$ & $31.96^{* * *}$ & 240 \\
F-statistic & $33.49^{* * *}$ & 240 & 240 & \\
$\mathrm{~N}$ & 240 & & & \\
\hline
\end{tabular}

Table 4B: Effect of advertising regulation on per capita magazine advertising

Dependent Variable: Real per capita advertising expenditures in national magazines

\begin{tabular}{lcccc}
\hline & $(1)$ & $(2)$ & $(3)$ & $(4)$ \\
\cline { 2 - 5 } Advertising & -0.14 & -0.08 & & \\
regulation & $(0.24)$ & $(0.24)$ & & -0.15 \\
Strict advertising & & & -0.08 & $(0.45)$ \\
regulation & & -0.05 & $(0.46)$ & -0.05 \\
Urbanization & & $(0.03)$ & & $(0.03)$ \\
& & 0.001 & & 0.001 \\
Real income per & & $(0.0008)$ & & $(0.0009)$ \\
capita & & $0.003^{* *}$ & & $0.003^{* *}$ \\
Manufacturing per & & $(0.001)$ & & $(0.001)$ \\
capita & & 0.76 & 0.75 & 0.76 \\
& & & & $13.99 * * *$ \\
Adjusted $\mathrm{R}^{2}$ & 0.76 & $24.88^{* * *}$ & $14.02 * * *$ & 240 \\
F-statistic & $13.99 * * *$ & 240 & \\
$\mathrm{~N}$ & 240 & 240 & & \\
\hline
\end{tabular}

State and year fixed effects for 1909, 1914, 1919, 1923 and 1929 are included in the estimation (1899 Census does not report magazine and newspaper advertising revenues separately). Robust-standard errors are reported in parentheses. Significance at the 10,5 , and 1 percent levels are denoted by $*, * *$, and $* * *$ respectively. 
Table 5: Difference-in-differences estimates of the effect of the 1914 Federal Trade Commission Act

\begin{tabular}{|c|c|c|c|c|}
\hline & $\begin{array}{c}\text { (1) } \\
\text { Dep var: } \\
\text { Real per } \\
\text { capita } \\
\text { advertising }\end{array}$ & $\begin{array}{c}\text { (2) } \\
\text { Dep var: } \\
\text { Real per } \\
\text { capita } \\
\text { advertising }\end{array}$ & $\begin{array}{c}\text { (3) } \\
\text { Dep var: } \\
\text { Share of } \\
\text { magazine } \\
\text { advertising }\end{array}$ & $\begin{array}{c}\text { (4) } \\
\text { Dep var: } \\
\text { Share of } \\
\text { magazine } \\
\text { advertising }\end{array}$ \\
\hline Advertising regulation & $10.10 * * *$ & -6.76 & 0.03 & -0.07 \\
\hline by 1914 & $(0.69)$ & $(4.52)$ & $(0.06)$ & $(0.23)$ \\
\hline FTC indicator & $\begin{array}{c}2.46^{* * *} \\
(0.42)\end{array}$ & $\begin{array}{l}1.23 \\
(0.78)\end{array}$ & $\begin{array}{l}-0.02 \\
(0.03)\end{array}$ & $\begin{array}{l}-0.03 \\
(0.06)\end{array}$ \\
\hline (FTC Indicator)*(Adv. & $1.39 * * *$ & $1.09 * *$ & 0.04 & $0.05^{*}$ \\
\hline Regulation by 1914) & $(0.50)$ & $(0.47)$ & $(0.03)$ & $(0.03)$ \\
\hline Urbanization & & $\begin{array}{l}0.17 * * \\
(0.08)\end{array}$ & & $\begin{array}{c}0.002 \\
(0.004)\end{array}$ \\
\hline Real per capita income & & $\begin{array}{c}0.001 \\
(0.002)\end{array}$ & & $\begin{array}{c}1.0 \times 10^{-5} \\
\left(8.0 \times 10^{-5}\right)\end{array}$ \\
\hline $\begin{array}{l}\text { Manufacturing per } \\
\text { capita }\end{array}$ & & $\begin{array}{c}0.006 * * * \\
(0.001)\end{array}$ & & $\begin{array}{c}-0.0001 \\
\left(9.0 \times 10^{-4}\right)\end{array}$ \\
\hline Adjusted $\mathrm{R}^{2}$ & 0.92 & 0.93 & 0.83 & 0.83 \\
\hline F-statistic & 65.52 & 69.48 & 81.29 & 49.62 \\
\hline $\mathrm{N}$ & 192 & 192 & 192 & 192 \\
\hline
\end{tabular}

State and year fixed effects for 1909, 1914, 1919 and 1923 are included in the estimation. Results are qualitatively similar if we do not include data for 1923. Robust-standard errors are reported in parentheses. Significance at the 10,5 , and 1 percent levels are denoted by $*, * *$, and $* * *$ respectively.

Notes: Advertising regulation by 1914 is an indicator variable to identify those states that had enacted a truth-in-advertising law by 1914. FTC indicator variable equals 1 for the years of 1914, 1919 and 1923. The interaction term is the product of these two indicators and is the variable of interest. 
Table 6A: Robustness check using placebo (accelerated) regulation instead of actual regulation

Dependent Variable: Real per capita advertising (in newspapers and magazines)

\begin{tabular}{|c|c|c|c|c|}
\hline & (1) & (2) & (3) & (4) \\
\hline Placebo (accelerated) & 0.24 & 0.27 & \multirow{10}{*}{$\begin{array}{l}1.05 \\
(0.72)\end{array}$} & \\
\hline advertising regulation & $(0.44)$ & $(0.40)$ & & \\
\hline Placebo (accelerated) strict & & & & 0.66 \\
\hline advertising regulation & & & & $(0.51)$ \\
\hline \multirow[t]{2}{*}{ Urbanization } & & -0.01 & & -0.01 \\
\hline & & $(0.05)$ & & $(0.50)$ \\
\hline \multirow[t]{2}{*}{ Real income per capita } & & $0.004 * * *$ & & $0.004 * * *$ \\
\hline & & $(0.001)$ & & $(0.001)$ \\
\hline \multirow{2}{*}{$\begin{array}{l}\text { Real manufacturing per } \\
\text { capita }\end{array}$} & & $0.009 * * *$ & & $0.009 * * *$ \\
\hline & & $(0.002)$ & & $(0.002)$ \\
\hline Adjusted $\mathrm{R}^{2}$ & 0.86 & 0.89 & 0.87 & 0.89 \\
\hline F-statistic & $33.91 * * *$ & $33.50 * * *$ & $33.18 * * *$ & 34.44 \\
\hline $\mathrm{N}$ & 288 & 288 & 288 & 288 \\
\hline
\end{tabular}

Table 6B: Robustness check using "delayed" advertising regulation

Dependent Variable: Real per capita advertising (in newspapers and magazines)

\begin{tabular}{|c|c|c|c|c|}
\hline & (1) & (2) & (3) & (4) \\
\hline $\begin{array}{l}\text { Delayed advertising } \\
\text { regulation }\end{array}$ & $\begin{array}{c}1.93 * * * \\
(0.43)\end{array}$ & $\begin{array}{c}1.75 * * * \\
(0.41)\end{array}$ & & \\
\hline $\begin{array}{l}\text { Delayed strict } \\
\text { advertising regulation }\end{array}$ & & & $\begin{array}{c}1.62 * * * \\
(0.62)\end{array}$ & $\begin{array}{l}1.36^{* *} \\
(0.58)\end{array}$ \\
\hline Urbanization & & $\begin{array}{l}-0.006 \\
(0.04)\end{array}$ & & $\begin{array}{r}-0.006 \\
(0.04)\end{array}$ \\
\hline Real income per capita & & $\begin{array}{c}0.005 * * * \\
(0.001)\end{array}$ & & $\begin{array}{c}0.004 * * * \\
(0.001)\end{array}$ \\
\hline $\begin{array}{l}\text { Real manufacturing } \\
\text { per capita }\end{array}$ & & $\begin{array}{l}0.008 * * * \\
(0.001)\end{array}$ & & $\begin{array}{c}0.009 * * * \\
(0.002)\end{array}$ \\
\hline Adjusted $\mathrm{R}^{2}$ & 0.87 & 0.90 & 0.87 & 0.90 \\
\hline F-statistic & $36.53 * * *$ & $43.11 * * *$ & $33.98 * * *$ & $40.54 * * *$ \\
\hline $\mathrm{N}$ & 288 & 288 & 288 & 288 \\
\hline
\end{tabular}

State and year fixed effects for $1899,1909,1914,1919,1923$ and 1929 are included in the estimation. Robust-standard errors are reported in parentheses. Significance at the 10, 5, and 1 percent levels are denoted by $* * *$, and $* * *$ respectively.

Notes: Placebo laws are constructed by coding a state as having introduced advertising regulation five years before it actually introduced regulation. "Delayed" laws are constructed by coding a state as having introduced advertising regulation five years after it actually introduced regulation. 
Table 7: Robustness check using tax revenues per capita as an alternative outcome variable

Dependent Variable: Real tax revenues per capita

\begin{tabular}{lcccc}
\hline & $(1)$ & $(2)$ & $(3)$ & $(4)$ \\
\cline { 2 - 4 } Advertising & -3.16 & $-3.43^{*}$ & & \\
regulation & $(2.06)$ & $(1.95)$ & & -1.38 \\
$\begin{array}{l}\text { Strict } \text { advertising } \\
\text { regulation }\end{array}$ & & -1.09 & $(1.63)$ \\
Urbanization & & 0.10 & $(1.50)$ & 0.09 \\
& & $(0.30)$ & & $(0.30)$ \\
Real income per & & -0.0001 & & 0.001 \\
capita & & $(0.01)$ & & $(0.01)$ \\
Manufacturing per & & $0.01^{*}$ & & $0.01^{*}$ \\
capita & & $(0.007)$ & & $(0.007)$ \\
& & 0.80 & & 0.80 \\
Adjusted $\mathrm{R}^{2}$ & 0.80 & $27.72^{* * *}$ & $25.97 * * *$ & $27.27 * * *$ \\
F-statistic & $28.93 * * *$ & 288 & 288 \\
N & 288 & 288 & 288 \\
\hline
\end{tabular}

Table 8: Did state-level advertising regulation have any effect on manufacturing per capita?

Dependent Variable: Real per capita manufacturing value

\begin{tabular}{lcccc}
\hline & $(1)$ & $(2)$ & $(3)$ & $(4)$ \\
\cline { 2 - 5 } Advertising regulation & 19.70 & 20.63 & & \\
& $(16.67)$ & $(17.82)$ & 26.02 & 23.54 \\
Strict advertising & & & $(18.01)$ & $(16.67)$ \\
regulation & & $8.66^{* *}$ & & $8.73^{* *}$ \\
Urbanization & & $(3.60)$ & & $(3.65)$ \\
& & $0.10^{* *}$ & & $0.10^{* *}$ \\
Real income per capita & & $(0.04)$ & & $(0.04)$ \\
& & & & \\
& & 0.91 & 0.89 & 0.91 \\
Adjusted $\mathrm{R}^{2}$ & & $86.83^{* * *}$ & $81.62^{* * *}$ & $89.43^{* *}$ \\
F-statistic & $79.92^{* * *}$ & 288 & 288 & 288 \\
$\mathrm{~N}$ & 288 & & \\
\hline
\end{tabular}

State and year fixed effects for 1899, 1909, 1914, 1919, 1923 and 1929 are included in the estimation. Robust-standard errors are reported in parentheses. Significance at the 10, 5, and 1 percent levels are denoted by $* * *$, and $* * *$ respectively. 


\section{Appendix Tables}

Table A1: Hazard models on the timing of the advertising regulation

\begin{tabular}{lcc}
\hline & $(1)$ & $(2)$ \\
\hline Advertising per capita & 1.01 & 0.79 \\
& $(0.25)$ & $(0.17)$ \\
Manufacturing per capita & $0.98^{* *}$ & $0.96^{* * *}$ \\
& $(0.01)$ & $(0.01)$ \\
Income per capita & 1.00 & $0.99^{* *}$ \\
& $(0.01)$ & $(0.01)$ \\
Urbanization & $1.08^{* *}$ & $1.13^{* * *}$ \\
& $(0.03)$ & $(0.04)$ \\
Progressive vote share in 1912 & & $1.07^{* * *}$ \\
& & $(0.02)$ \\
Civil service merit reform & & $6.44^{*}$ \\
& & $(7.03)$ \\
Initiative and referenda & & 1.05 \\
& & $(0.45)$ \\
Direct primaries & & 1.16 \\
& & $(0.43)$ \\
Child labor reform & & 1.99 \\
& & $(0.97)$ \\
Log-likelihood & -34.2 \\
$\chi^{2}$-statistic & -41.3 & $37.3 * * *$ \\
$\mathrm{~N}$ & $43.9 * *$ & 41 \\
\hline
\end{tabular}

Hazard ratios are shown. Robust-standard errors are reported in parentheses. Significance at the 10, 5, and 1 percent levels are denoted by $*, * *$, and $* * *$ respectively.

Notes: Data on progressive votes of 1912 were from the Historical Statistics of the United States. Data on other Progressive Era reform measures such as civil service merit reform, initiative and referenda, direct primaries and child labor reform are graciously provided by Price Fishback on his website. 
Table A2: Logit estimation of U.S. Senate voting on the Federal Trade Commission Act of 1914

Dependent Variable: Binary variable on senator's vote on FTC Act (yes =1)

\begin{tabular}{|c|c|c|c|c|}
\hline & (1) & (2) & (3) & (4) \\
\hline $\begin{array}{l}\text { Advertising } \\
\text { regulation by } 1914\end{array}$ & $\begin{array}{l}-1.08 \\
(1.44)\end{array}$ & $\begin{array}{c}0.39 \\
(1.31)\end{array}$ & & \\
\hline $\begin{array}{l}\text { Advertising } \\
\text { expenditures per } \\
\text { capita }\end{array}$ & & & $\begin{array}{l}-0.23 \\
(0.36)\end{array}$ & $\begin{array}{l}-0.30 \\
(0.47)\end{array}$ \\
\hline Urbanization & & $\begin{array}{c}-14.49 * * \\
(7.19)\end{array}$ & & $\begin{array}{l}-11.27 \\
(7.08)\end{array}$ \\
\hline Income per capita & & $\begin{array}{c}0.01 \\
(0.02)\end{array}$ & & $\begin{array}{c}0.014 * * \\
(0.007)\end{array}$ \\
\hline $\begin{array}{l}\text { Manufacturing per } \\
\text { capita }\end{array}$ & & $\begin{array}{c}0.02 \\
(0.02)\end{array}$ & & $\begin{array}{c}0.01 \\
(0.02)\end{array}$ \\
\hline First dimension & $-13.13 * * *$ & $-15.30 * * *$ & $-13.20 * * *$ & $-15.37 * * *$ \\
\hline D-Nominate & $(3.05)$ & $(3.14)$ & (3.32) & $(3.21)$ \\
\hline Second dimension & 0.51 & -0.71 & 0.22 & -0.52 \\
\hline D-Nominate & (1.79) & $(1.38)$ & $(1.37)$ & $(1.26)$ \\
\hline Republican & $\begin{array}{l}4.82 * \\
(2.92)\end{array}$ & $\begin{array}{l}5.64 * * \\
(2.59)\end{array}$ & $\begin{array}{l}4.75 \\
(3.01)\end{array}$ & $\begin{array}{l}5.79 * * \\
(2.75)\end{array}$ \\
\hline $\begin{array}{l}\text { Progressive vote } \\
\text { share in } 1912\end{array}$ & $\begin{array}{l}4.06 \\
(4.04)\end{array}$ & $\begin{array}{c}1.82 \\
(4.66)\end{array}$ & $\begin{array}{c}4.14 \\
(0.31)\end{array}$ & $\begin{array}{c}2.45 \\
(4.38)\end{array}$ \\
\hline McFadden $\mathrm{R}^{2}$ & 0.66 & 0.70 & 0.65 & 0.70 \\
\hline LR-statistic & $49.28 * * *$ & $52.05 * * *$ & $48.83 * * *$ & $52.01 * * *$ \\
\hline $\mathrm{N}$ & 69 & 69 & 69 & 69 \\
\hline
\end{tabular}

Robust-standard errors are reported in parentheses. Significance at the 10, 5, and 1 percent levels are denoted by $* * *$, and $* * *$ respectively.

Notes: Senators who did not vote were excluded from the regression. We used an indicator variable that equals 1 if the state had enacted a truth-in-advertising law before 1914 or per capita advertising expenditures as proxies for advertising interests. First and second dimension D-Nominate scores, which are often used in the voting literature to proxy for a Senator's ideology, a dummy variable indicating if the Senator was a Republican, and the percentage of the state's vote in 1912 that was for the Progressive Party are included as additional explanatory variables. 